\title{
In Vitro Propagation of Tribulus terrestris with IAA and BAP Concentrations
}

\author{
Samanhudi $^{1,2^{*}}$, Ahmad Yunus ${ }^{1,2}$, and Rahmanto ${ }^{1}$ \\ ${ }^{1}$ Department of Agrotechnology, Faculty of Agriculture, Universitas Sebelas Maret, Jl. Ir. Sutami 36A \\ Kentingan Jebres Surakarta 57126, Indonesia \\ ${ }^{2}$ Center for Biotechnology and Biodiversity Research and Development, Institute of Research and Community \\ Services, Universitas Sebelas Maret, Jl. Ir. Sutami 36A Kentingan Jebres Surakarta 57126, Indonesia \\ *Corresponding author: samanhudi@staff.uns.ac.id
}

\begin{abstract}
Tribulus terrestris is conventionally propagated using seeds but has limited germination capacity. One approach that can be done for this plant multiplication is in vitro tissue culture. This study was conducted to determine the growth potential of $T$. terrestris in vitro by the addition of auxin (IAA) and cytokinin (BAP) as growth regulators at several concentrations. The study was conducted at the Laboratory of Plant Physiology and Biotechnology, Faculty of Agriculture, Universitas Sebelas Maret Surakarta from February to December 2017. The experiment employed factorial Completely Randomized Design (CRD) method with 2 factors, namely IAA concentration ( 0 ppm, 0.1 ppm, 0.2 $\mathrm{ppm}, 0.3 \mathrm{ppm})$, and BAP concentration (0 ppm, $0.3 \mathrm{ppm}, 0.5 \mathrm{ppm}, 0.7 \mathrm{ppm})$. The observed growth parameters were shoot emergence time, leaf emergence time, root emergence time, number of leaves, and number of roots. Data were analyzed using analysis of variance followed by DMRT with a $95 \%$ confidence level. The results showed that the addition of IAA only affects leaf emergence time, while the addition of BAP had a significant effect on the leaf emergence time and number of leaves. The interactions between IAA and BAP had a significant effect on leaf emergence time.
\end{abstract}

Keywords: explant; plant growth; tissue culture

Cite this as: Samanhudi, Yunus, A. and Rahmanto. (2021). In Vitro Propagation of Tribulus terrestris with IAA and BAP Concentrations. Journal of Biodiversity and Biotechnology. 1(1), 17-25. doi: https://dx.doi.org/10.20961/jbb.v1i1.50245

\section{Introduction}

Tribulus terrestris L. (Zygophyllaceae) is a plant that originates from the Mediterranean region and has been spread widely in warm climate regions such as Africa, Australia, and Asia (1). This plant is used in the practice of Chinese medicine for several diseases (2). Tribulus plant contains several active chemicals that are used as antibiotics and contain steroidal substances that function as an aphrodisiac. One of the main characteristics of this plant is the high amount of steroid chemicals contents. Steroid saponins, diosgenin, furostanol, spirostanol, tigogenin, ruscogenin, chlorogenin, and gitogenin are important chemical constituents which contents are very high in $T$. terrestris (3). The plant is rich in protein and calcium and also contains oil, peroxidase, diastase, resins, and even various glucosides in dried fruit from $T$. terrestris. These characteristics make $T$. terrestris a valuable plant for medicines and other uses such as stimulants and stamina enhancers (4).

Tribulus terrestris is conventionally propagated using seeds. Based on a study conducted on the multiplication of seeds, the germination rate capability by the seeds of this plant is very small (5). In Indonesia, the cultivation of this plant is quite difficult because it can only grow in certain conditions and times. In one year, cultivation can only be done one season in early May to August. The characteristics of seed dormancy and low germination from Tribulus terrestris makes this plant a suitable specimen for the study and development of plant propagation methods by in vitro tissue culture methods. The plant's tissue culture aims to provide information about the correct method in propagation by micropropagation for the purpose of seed 
formation from cultured plantlets and other utilities. This also opens the pathway to medicinal substance production of $T$. terrestris secondary metabolite within the method of a bioreactor in vitro as the substitution for cultivation by means of a more sustainable method of agricultural production.

Modification of tissue culture media by regulating growth regulators needs to be done to increase the percentage of plant growth rate in tissue culture by means of propagation. There are two types of plant hormones (auxin and cytokinin) that are widely used in propagation in vitro. This experiment aims to observe whether the addition of IAA (Indoleacetic Acid) and BAP (Benzyl Amino Purine) at certain concentrations can promote Tribulus terrestris plant's grown in tissue culture.

\section{Material and Methods}

The research was conducted from February to December 2017 at the Laboratory of Plant Physiology and Biotechnology, Faculty of Agriculture, Universitas Sebelas Maret. The material used in this study were the seed sprouts of Tribulus terrestris plants as explants. The medium used was MS type, with aqua dest composition, sugar $(80 \mathrm{~g} / \mathrm{L})$, macronutrient solution $(50 \mathrm{ppm})$, micronutrient solution (5 ppm), vitamins (50 ppm), Fe-EDTA solution (50 ppm), IAA (Indoleacetic Acid) and BAP (Benzyl Amino Purine), Kinetin (0.3 ppm), white agar $(8 \mathrm{~g} / \mathrm{L})$, spiritus fuel, methanol, $70 \%$ alcohol, formalin, 5\% chlorox, detergent, fungicide (Mankozeb) $0.1 \mathrm{~g} / 100 \mathrm{~mL}$, bactericidal (Agrept/Streptomycin) $0.1 \mathrm{~g} / 100$ $\mathrm{mL}$, antibiotic solution (amoxycillin) $0.1 \mathrm{~g} / 100$ $\mathrm{mL}$, ascorbic acid, and betadine $2 \mathrm{~mL} / 100 \mathrm{~mL}$. The tools used included autoclave, laminar airflow cabinet (LAFC), oven, bunsen lamp, hand sprayer, culture bottle, measuring cup, analytic scale, hot plate stirrer, tweezers, scalpel knife, $\mathrm{pH}$ meter, pipette, cutter, and petri dish. This research was carried out using a completely randomized design (CRD) with two factors. The first factor was the addition of auxin growth regulator of Indole-acetic Acid (IAA) $(0 ; 0.1 ; 0.2 ; 0.3 \mathrm{ppm})$ and the second factor was the addition of cytokinin growth regulator of Benzyl Amino Purine (BAP) (0; $0.3 ; \quad 0.5 ; \quad 0.7 \quad \mathrm{ppm})$. Research activities initialized by tools and materials preparation, explant sterilization, explant inoculation, and data observation. Data observation was done within 60 days after planting. The variables observed in this study were shoot emergence time (the day after planting/DAP), leaves emergence time (DAP), number of leaves, root emergence time (DAP), and number of roots. The obtained data were analyzed using analysis of variance followed by further DMRT (Duncan Multiple Range Test) with a confidence level of $95 \%$.

\section{Results and Discussion}

Shoot emergence time

The appearance of shoots is an indicator in tissue culture studies that plants can grow and develop with the given treatment. The growth and regeneration process is determined by three factors, which are cultivar selection of explant used with certain regeneration capability, explant source optimization, and media adaptation to the given genotype (6). Embryo culture has shoot growth characteristics that emerged between cotyledons, characterized by the appearance of plumula. Adaptation of explants in in-vitro media is determined by nutrient availability factors, microclimate conditions that are following ex-vitro conditions, and additional concentrations of growth promoter (7). The mean value of shoots emergence time with various IAA and BAP concentrations were shown in Figure 1.

The fastest shoot emergence time was shown by the treatment of 0 ppm IAA and 0.7 ppm BAP which was 8.67 DAP, while the latest shoot emergence time shown by 0.3 ppm IAA and $0.3 \mathrm{ppm}$ BAP which was 22.67 DAP. Based on the average value of shoot emergence time from IAA treatment independently, the response of the fastest shoot time was shown in the treatment of 0 ppm IAA, which was about 13 DAP on average, while the longest shoot emergence time was shown at 0.3 ppm IAA which was 19 DAP in average. This showed that the use of BAP independently without the addition of IAA has been able to give better shoot emergence times than the addition of IAA. Despite this result, another study on Cucumis melo L. (8) showed that IAA and BAP independently did not significantly affect the regeneration and shoot induction, but the combination of both proved highly affecting differentiation, development, and elongation of new buds. 


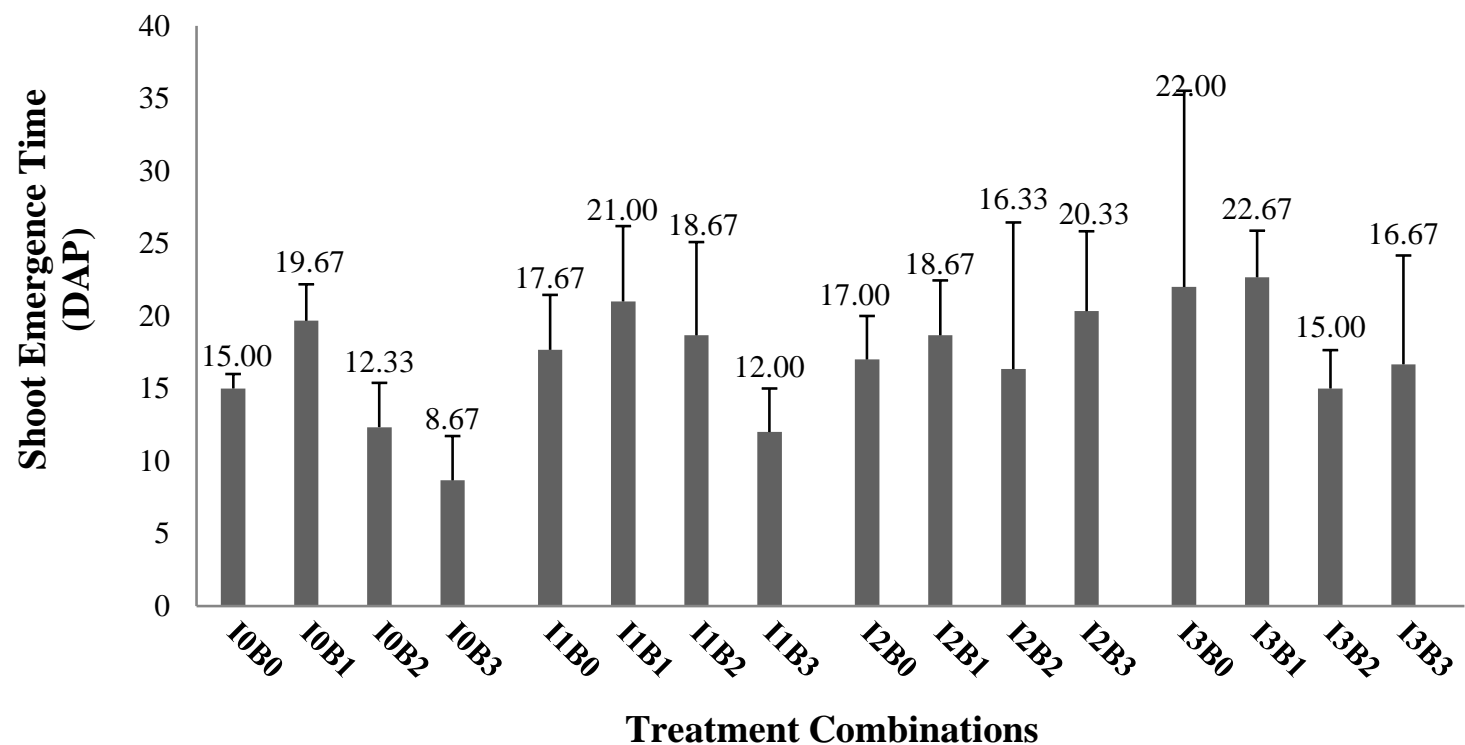

Description: I0B0: IAA 0 ppm + BAP 0 ppm; IOB1: IAA 0 ppm + BAP 0.3 ppm; I0B2: IAA 0 ppm + BAP 0.5 ppm; I0B3: IAA 0 ppm + BAP 0.7 ppm; I1B0: IAA 0.1 ppm + BAP 0 ppm; I1B1: IAA 0.1 ppm + BAP 0.3 ppm; I1B2: IAA 0.1 ppm + BAP 0.5 ppm; I1B3: IAA 0.1 ppm + BAP 0.7 ppm; I2B0: IAA 0.2 ppm + BAP 0 ppm; I2B1: IAA 0.2 ppm + BAP 0.3 ppm; I2B2: IAA $0.2 \mathrm{ppm}+$ BAP $0.5 \mathrm{ppm}$; I2B3: IAA $0.2 \mathrm{ppm}+$ BAP $0.7 \mathrm{ppm}$; I3B0: IAA 0.3 ppm + BAP 0 ppm; I3B1: IAA 0.3 ppm + BAP 0.3 ppm; I3B2: IAA 0.3 ppm + BAP 0.5 ppm; I3B3: IAA 0.3 ppm + BAP 0.7 ppm.

Figure 1. The average time of shoot emergence in various IAA and BAP concentrations

Leaf primordia have accumulated IAA in apical tissue (9). This endogenous IAA content provides the needs of explants to carry out the growth process. The addition of exogenous IAA made the IAA concentration used by explant tissue to be excessive and not optimal, which resulted in growth inhibition. This was indicated by the lower average value of shoot emergence time from the use of IAA concentrations when the concentration was increased. An increase in IAA concentration did not affect the growth of shoot biomass on tomato seeds (10). Auxin at lower concentrations compared to cytokinins is needed in the shoot induction process because the combination of the two with the appropriate concentration will accelerate the process of cell division (11).

Table 1. The effect of BAP treatment on average shoot emergence time (DAP)

\begin{tabular}{lcccc}
\hline & \multicolumn{4}{c}{ BAP Concentration (ppm) } \\
\cline { 2 - 5 } & 0 & 0.3 & 0.5 & 0.7 \\
\hline $\begin{array}{l}\text { Shoot } \\
\text { emergence } \\
\text { time }\end{array}$ & $17.91^{\mathrm{ab}}$ & $20.5^{\mathrm{b}}$ & $15.58^{\mathrm{ab}}$ & $14.41^{\mathrm{a}}$ \\
\hline
\end{tabular}

Description: Number followed by the same letters showed no significant difference $(\mathrm{P}<0.05)$.

Based on the results in Table 1 , the fastest shoot emergence time was indicated by the treatment of $0.7 \mathrm{ppm}$ BAP independently which was 14.41 DAP; while the slowest shoot emergence time was shown in the use of 0.3 ppm BAP which was 20.5 DAP. Table 1 showed that a higher concentration of BAP in the treatments brought a faster explant shoot emergence time. The addition of BAP to tissue culture can increase the growth rate of shoots, so BAP is often used in tissue culture due to this several superior properties compared to other types of cytokines $(12,13)$.

Table 2. The result of the analysis of the various uses of IAA and BAP concentrations on the leaves emergence time.

\begin{tabular}{lc}
\hline Treatments & Leaf Emergence Time \\
\hline IAA & $0.011^{*}$ \\
BAP & $0.000^{* *}$ \\
IAA * BAP & $0.000^{* *}$ \\
\hline
\end{tabular}

Description: * has a significant effect $(\mathrm{P}<0.05)$, ** has a very significant effect $(\mathrm{P}<0.01)$

\section{Leaves emergence time}

Leaf formation in explants has a function to carry out essential physiological processes such as photosynthesis which is used as a place energy generator for other physiological processes such as cell proliferation and organogenesis. Time of leaf emergence was positively correlated with leaf growth and biomass (14). The results of variance analysis 
of leaves emergence time of Tribulus terrestris explants at several IAA and BAP concentrations are shown in Table 2.

Based on the results in Table 2, all treatments of IAA, BAP, and combination concentrations have a significant effect on the growth response of leaves emergence time.
Changes in leaf growth, leaf area, and biomass were followed by changes in the content of cytokinin concentrations in the media and tissues (15). The effect of IAA and BAP concentrations combination on the response of leaves emergence time is shown in Table 3.

Table 3. Effect of IAA and BAP concentrations on leaves emergence time (DAP)

\begin{tabular}{lcccc}
\hline & \multicolumn{4}{c}{ BAP Concentration $(\mathrm{ppm})$} \\
\cline { 2 - 5 } IAA Concentration $(\mathrm{ppm})$ & 0 & 0.3 & 0.5 & 0.7 \\
\hline 0 & $18.33^{\mathrm{abcd}}$ & $26.00^{\text {def }}$ & $28.00^{\mathrm{ef}}$ & $16.67^{\mathrm{abc}}$ \\
0.1 & $26.00^{\text {def }}$ & $25.33^{\text {def }}$ & $15.00^{\mathrm{ab}}$ & $16.00^{\mathrm{abc}}$ \\
0.2 & $23.33^{\text {cde }}$ & $24.00^{\text {cde }}$ & $12.50^{\mathrm{a}}$ & $25.00^{\text {def }}$ \\
0.3 & $32.75^{\mathrm{f}}$ & $26.33^{\text {def }}$ & $19.33^{\mathrm{abcd}}$ & $22.33^{\text {bcde }}$ \\
\hline
\end{tabular}

Description: Number followed by the same letters shows no significant difference in DMRT test of $5 \%$ level.

Table 3 showed the fastest response time for leaf emergence was indicated by of the 0.2 ppm IAA and 0.5 ppm BAP treatments, which were 12.5 DAP; while the latest leaves emergence time was shown by $0.3 \mathrm{ppm}$ IAA and 0 ppm BAP which was 32.75 DAP. The use of 0.2 ppm IAA concentration and $0.5 \mathrm{ppm}$ BAP was able to increase the response rate of leaf emergence by $160 \%$ faster than the use of 0.3 ppm IAA and 0 ppm BAP with a very significant difference.

Based on the average value of the IAA treatment, the fastest response time of leaves appearance time was shown in 0.1 ppm IAA, which was 20.58 DAP, while the highest average value of leaves emergence time was shown by 0.3 ppm IAA which was 25.5 DAP. This showde that the use of IAA at low concentrations in this study gave better results in the growth response of leaf organogenesis compared to high IAA concentrations. The growth rate of shoots and the average time of shoot emergence decreased with increasing concentration of auxin in the media, which indicates that excess exogenous auxin actually reduces the rate of organogenesis (16). Depending on concentration and tissue, auxin stimulates or inhibits cell elongation. Thus, differential auxin is stimulated and distributed to all organs, such as roots or stems, leading to differential growth which results in organ formation (17).

The average time of leaf emergence on the use of BAP concentration independently showed the fastest value in the treatment of BAP $0.5 \mathrm{ppm}$ which was 18.83 DAP. The average time of leaf emergence was indicated by the use of BAP with a concentration of 0 and
$0.1 \mathrm{ppm}$ with a value of 25.54 DAP on average. This data showed the different effects of BAP concentration on the growth response of shoots emergence time, with the fastest shoot emergence time indicated by BAP $0.7 \mathrm{ppm}$. Cytokinins have an important role in bud and root formation, regulate seed development, abiotic stress, and plant senescence $(18,19,20$, $21,22)$. The role of BAP as the most stable type of cytokinin is to encourage cell proliferation, tissue lengthening, and tissue enlargement. Hamad and Taha (23) showed that a positive correlation between the number of shoots, total weight, total length, biomass, and propagule from the results of the tissue cell proliferation process was obtained from media added with the concentration of BAP.

\section{Root emergence time}

Roots emergence indicates good explant growth. Root induction is influenced predominantly by auxin activity in explants. Research about in vitro culture of Pecan plants by Zhang et al. (24) showed that exogenous auxin had an effective influence on root growth. IAA content in meristematic tissues can trigger root growth as apical meristem tissue. IAA as phytohormone can regulate many aspects of plant growth and development, such as branching in shoots and roots, as well as differentiation of the vascular vessel system $(25,26)$. Apart from playing a role in organogenesis in the apical meristem, IAA also determines the regulation of phyllotaxis (27). The effect of the use of IAA and BAP growth regulators on the root emergence time in Tribulus terrestris explants is presented in Figure 2. 


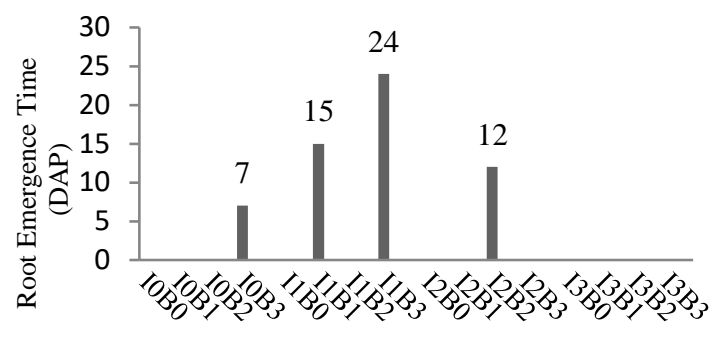

Treatment Combinations

Description: I0B0: IAA 0 ppm + BAP 0 ppm; I0B1: IAA 0 ppm + BAP 0.3 ppm; I0B2: IAA 0 ppm + BAP 0.5 ppm; I0B3: IAA $0 \mathrm{ppm}+$ BAP $0.7 \mathrm{ppm}$; I1B0: IAA $0.1 \mathrm{ppm}+$ BAP 0 ppm; I1B1: IAA $0.1 \mathrm{ppm}+$ BAP 0.3 ppm; I1B2: IAA $0.1 \mathrm{ppm}+$ BAP $0.5 \mathrm{ppm}$; I1B3: IAA $0.1 \mathrm{ppm}+$ BAP $0.7 \mathrm{ppm}$; I2B0: IAA $0.2 \mathrm{ppm}+\mathrm{BAP} 0 \mathrm{ppm}$; I2B1: IAA $0.2 \mathrm{ppm}+$ BAP $0.3 \mathrm{ppm}$; I2B2: IAA $0.2 \mathrm{ppm}+$ BAP 0.5 ppm; I2B3: IAA $0.2 \mathrm{ppm}+$ BAP 0.7 ppm; I3B0: IAA 0.3 ppm + BAP 0 ppm; I3B1: IAA 0.3 ppm + BAP 0.3 ppm; I3B2: IAA $0.3 \mathrm{ppm}+$ BAP $0.5 \mathrm{ppm}$; I3B3: IAA $0.3 \mathrm{ppm}+$ BAP $0.7 \mathrm{ppm}$.

Figure 2. The root emergence time of Tribulus terrestris explant with various concentrations of IAA and BAP

Figure 2 showed that not all samples were able to grow roots. The root can only grow in 4 treatments, which were 0 ppm IAA and 0.7 ppm BAP; IAA 0.1 ppm and BAP 0.3 ppm; IAA $0.1 \mathrm{ppm}$ and BAP 0.7 ppm; $0.2 \mathrm{ppm}$ IAA and 0.5 ppm BAP. Roots emergence time ranged from 7-24 DAP with the fastest response root appearance time on the treatment of $0 \mathrm{ppm}$ IAA and 0.7 ppm BAP which is 7 DAP and the latest root emergence time in the treatment of $0.1 \mathrm{ppm}$ IAA and $0.7 \mathrm{ppm}$ BAP.

The absence of roots in most of the samples was suspected because the condition of the radicular tissue in the newly planted explants was not in good condition. This was shown in the visual observations that most of the roots grow from newly grown sprouts are transparent and withered in color media, indicate that the tissue that has been died caused by the sterilization process. The root induction in some samples comes from the buds of the new roots from the root base, not the lateral root shoots of the radicular development. Besides being due to the dead radicular tissue conditions, the influence of auxin was also thought to play a role in the growth response. This was showed by the control treatment without external IAA addition which can still grow roots. IAA used in the media is thought to have not been in optimal condition since the sterilization process in the autoclave. IAA's ability as a plant growth regulator will experience a reduction in enzymatic work at high temperatures (28).
Number of leaves

Leaves are one of the organs of plants that are very important especially for photosynthesis which is used as a food production factory and supports optimum growth (29). The number of leaves is one of the important indicators in determining tissue potential which is regulated by genetic factors and growth hormone. The analysis result of the effects of IAA and BAP growth regulators on the response of leaf growth in Tribulus terrestris are shown in Table 4.

Table 4. Analysis result of various IAA and BAP concentrations effect on the number of leaves

\begin{tabular}{lc}
\hline Treatment & Number of Leaves \\
\hline IAA & $0.518^{\text {ns }}$ \\
BAP & $0.050^{*}$ \\
IAA * BAP & $0.238^{\text {ns }}$ \\
\hline Description: * has a significant effect, ${ }^{\text {ns }}$ has no \\
significant effect.
\end{tabular}

Table 4 showed that the addition of BAP independently has a significant influence on the number of leaves $(\mathrm{P}<0.05)$. The effect of IAA addition and the interaction between IAA and BAP on the number of leaves did not occur. Akhiriana et al. (30), suggested that the addition of IAA was independently able to affect the process of leaves formation, especially in a low concentration of $0.15 \mathrm{ppm}$. The previous research showed that significant changes in leaf growth, leaf area, and biomass were followed by changes in the content of cytokinin concentrations in the media and tissues (15). The average number of leaves from the treatment given by various IAA and BAP concentrations were shown in Figure 3.

Figure 3 showed the highest average response value of the number of leaves which were indicated by the treatment of $0.1 \mathrm{ppm}$ IAA and $0.7 \mathrm{ppm}$ BAP with 2.33 strands; while the least average number of leaves was 1 piece which obtained by 4 different treatments: IAA $0.1 \mathrm{ppm}$ and BAP 0 ppm; 0.2 ppm IAA and 0 ppm BAP; 0.2 ppm IAA and 0.7 ppm BAP; and IAA $0.3 \mathrm{ppm}$ and BAP $0 \mathrm{ppm}$. One of the roles of auxin in leaf growth is to help the development of meristem tissue of leaf induction (29). Cytokinin such as BAP in leaf formation is used for morphogenesis and leaves enlargement and the result will be used for growth and increasing the number of leaves (31). 


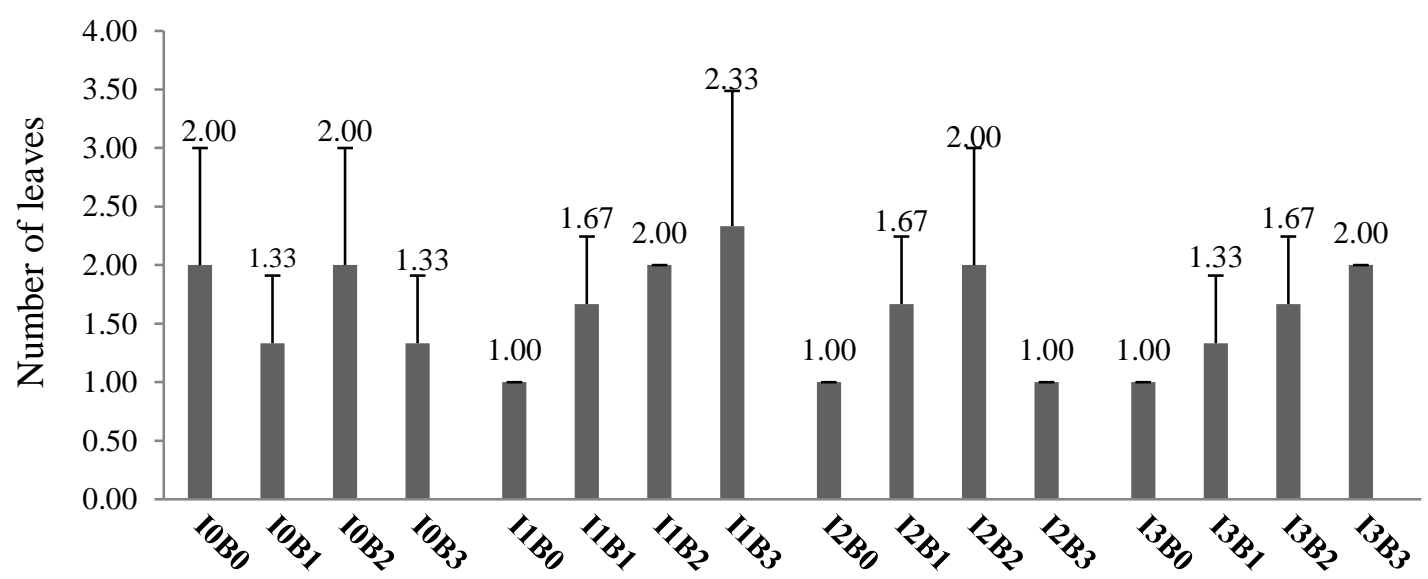

Treatment combinations

Description: I0B0: IAA 0 ppm + BAP 0 ppm; I0B1: IAA 0 ppm + BAP 0.3 ppm; I0B2: IAA 0 ppm + BAP 0.5 ppm; I0B3: IAA 0 ppm + BAP 0.7 ppm; I1B0: IAA 0.1 ppm + BAP 0 ppm; I1B1: IAA 0.1 ppm + BAP 0.3 ppm; I1B2: IAA 0.1 ppm + BAP 0.5 ppm; I1B3: IAA 0.1 ppm + BAP 0.7 ppm; I2B0: IAA 0.2 ppm + BAP 0 ppm; I2B1: IAA 0.2 ppm + BAP 0.3 ppm; I2B2: IAA $0.2 \mathrm{ppm}+$ BAP 0.5 ppm; I2B3: IAA $0.2 \mathrm{ppm}+$ BAP 0.7 ppm; I3B0: IAA 0.3 ppm + BAP 0 ppm; I3B1: IAA 0.3 ppm + BAP 0.3 ppm; I3B2: IAA 0.3 ppm + BAP 0.5 ppm; I3B3: IAA 0.3 ppm + BAP 0.7 ppm.

Figure 3. The average number of leaves of $T$. terrestris explant with various concentrations of IAA and BAP

Table 5. The effect of BAP concentrations on the number of leaves

\begin{tabular}{lcccc}
\hline & \multicolumn{4}{c}{ BAP Concentration Treatment } \\
& 0 & 0.3 & 0.5 & 0.7 \\
\hline $\begin{array}{l}\text { Number of } \\
\text { Leaves }\end{array}$ & $1.25^{\mathrm{a}}$ & $1.33^{\mathrm{a}}$ & $1.97^{\mathrm{b}}$ & $1.67^{\mathrm{ab}}$ \\
\hline
\end{tabular}

Description: Number followed by the same letters shows no significant difference in DMRT test of $5 \%$ level.

The use of $0.5 \mathrm{ppm}$ BAP concentration independently showed a significantly different and greater effect compared to the concentration of BAP $0 \mathrm{ppm}$ and $0.3 \mathrm{ppm}$. The concentration of BAP of $0.7 \mathrm{ppm}$ gave a relatively lower average number of leaves compared to the number of leaves from the treatment of a $0.5 \mathrm{ppm}$ BAP concentration. Thus, the concentration of BAP of $0.5 \mathrm{ppm}$ was assumed as the best concentration in this study with regard to the number of leaves. Table 5 shows that the number of leaves tends to increase in line with the increase in BAP concentration. This followed the previous research by Kristina (31) which stated that cytokines such as BAP in leaf formation have a role in morphogenesis and leaves enlargement which is used for supporting the growth and increase the number of additional leaves. The role of BAP in leaf formation is more dominant than the effect of IAA.

Higher number of leaves formed will give more energy for explant tissue to grow.
The increasing number of leaves and leaf area width will support the growth and yield of plants, due to the increasing number of leaves that allow more sunlight to be received which improve photosynthesis rate, produce many photosynthates which then stored as carbohydrates (32).

\section{Number of roots}

High quantity, large, and long-sized roots are very useful for the absorption of nutrients from the media because the field of absorption of nutrients from the media will be wide. Roots can be formed optimally on the media if supported by the appropriate concentration of growth regulator, especially from the auxin group. The number of roots is an indicator of the ability of total tissue potential. Although in embryo culture the explants have formed roots, the supplementation of auxin and cytokinin will trigger explants to form additional roots. The effect of the use of IAA and BAP growth regulators on the number of Tribulus terrestris roots is shown in Figure 4.

Figure 5 showed that not all explant samples observed can grow roots. Root only appears in 4 treatments, which were 0 ppm IAA and $0.7 \mathrm{ppm}$ BAP; $0.1 \mathrm{ppm}$ IAA and $0.3 \mathrm{ppm}$ BAP; $0.1 \mathrm{ppm}$ IAA and $0.7 \mathrm{ppm}$ BAP; $0.2 \mathrm{ppm}$ IAA and $0.5 \mathrm{ppm}$ BAP. The highest number of roots was produced by explants with the treatment of $0.1 \mathrm{ppm}$ IAA and $0.7 \mathrm{ppm}$ BAP which was 4 pieces, while the smallest number 
of roots was shown by explants from 0 ppm IAA treatment and $0.7 \mathrm{ppm}$ BAP.

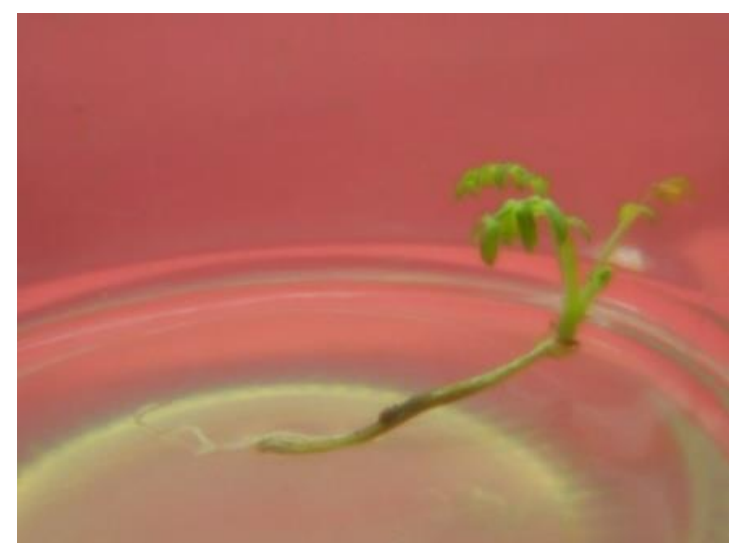

Figure 4. T. terretris explant with $0.1 \mathrm{ppm}$ IAA and $0.3 \mathrm{ppm}$ BAP with 3 strands of leaves

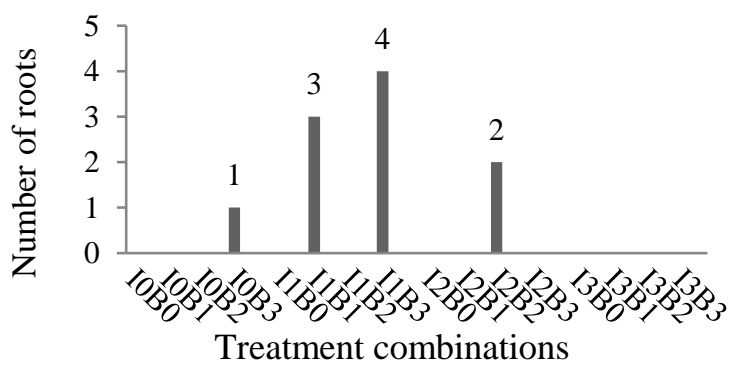

Description: I0B0: IAA 0 ppm + BAP 0 ppm; I0B1: IAA 0 ppm + BAP 0.3 ppm; I0B2: IAA 0 ppm + BAP 0.5 ppm; I0B3: IAA 0 ppm + BAP 0.7 ppm; I1B0: IAA $0.1 \mathrm{ppm}+$ BAP 0 ppm; I1B1: IAA $0.1 \mathrm{ppm}+$ BAP 0.3 ppm; I1B2: IAA $0.1 \mathrm{ppm}+$ BAP $0.5 \mathrm{ppm}$; I1B3: IAA $0.1 \mathrm{ppm}+$ BAP $0.7 \mathrm{ppm}$; I2B0: IAA $0.2 \mathrm{ppm}+$ BAP $0 \mathrm{ppm}$; I2B1: IAA $0.2 \mathrm{ppm}+$ BAP $0.3 \mathrm{ppm}$; I2B2: IAA $0.2 \mathrm{ppm}+$ BAP 0.5 ppm; I2B3: IAA $0.2 \mathrm{ppm}+$ BAP 0.7 ppm; I3B0: IAA 0.3 ppm + BAP 0 ppm; I3B1: IAA 0.3 ppm + BAP 0.3 ppm; I3B2: IAA $0.3 \mathrm{ppm}+$ BAP $0.5 \mathrm{ppm}$; I3B3: IAA $0.3 \mathrm{ppm}+$ BAP 0.7 ppm.

Figure 5. The number of root from various IAA and BAP concentrations

From the data, we cannot yet conclude the influence of each type of growth regulator treatment on the growth response of root growth. The addition of IAA can increase the formation of root numbers but this does not mean that without the external IAA, explants can't grow roots. Root induction as meristem tissue is dominantly affected by the function of endogen auxin such as IAA (33). It was because explants used in this research already have an endogenous growth regulator, so that the content of endogenous IAA might have beed sufficient to grow roots. Root cells generally contain enough or almost enough auxin to elongate normally. Therefore, the addition of hormones is expected to stimulate faster and denser rootd growth.

The number of roots has a positive effect on explant growth. From all four explants that produce roots, their growth response by the number of leaves and the life span of the media which were relatively larger than the treatments that does not give rise to roots. This was due to the high number of roots increased the amount of nutrient uptake by explants. The inability of other explants in inducing roots was thought to be because the content of endogenous auxin was not able to stimulate the organogenesis process, especially the formation of lateral roots so that the addition of auxin concentration is needed.

\section{Conclusion}

The addition of IAA independently did not affect all explant growth variables observed, whereas the addition of BAP affects the growth response on leaves emergence time and the number of leaves. The combination treatment of $0.2 \mathrm{ppm}$ IAA and $0.5 \mathrm{ppm}$ BAP was a growth regulator concentration with the greatest effect on the leaves emergence time response, which was $12.5 \mathrm{DAP}$.

\section{Acknowledgment}

The authors would like to thank The Ministry of Research, Technology, and Higher Education of Indonesia who has funded this research through the scheme of Insentif Riset SINas (INSINas) for the fiscal year 2017.

\section{Conflict of Interest}

All authors declare no conflicts of interest in this paper.

\section{References}

1. Sharifi S. Enhanced callus induction and high-efficiency plant regeneration in Tribulus terrestris L., an important medicinal plant. Journal of Medicinal Plants Research, 2012;6(27):4401-4408. https://doi.org/10.5897/jmpr12.260.

2. Austin DF.. Handbook of medicinal herbs. Second Edition. In Economic Botany, 2006;57(2):290.https://doi.org/10.1663/00 13-0001(2003)057[0290:homhse]2.0.co;2

3. Xiong W, Luo G, Zhou L, Zeng Y, Yang W. In vitro and in vivo antitumor effects of acetylshikonin isolated from Arnebia euchroma (Royle) Johnst (Ruanzicao) cell 
suspension cultures. Chinese Medicine, 2009;4:1-7. https://doi.org/10.1186/17498546-4-14

4. Jiji MJ, Visalakshi S, Meenakshi P, Rathi MA, Thirumoorthi L, Chinna GD, Gopalakrishnan VK. Antilipidemic activity of Cissus quadrangularis and Tribulus terrestris on obesity in high fat fed rats. Pharmacologyonline, 2009;2: 1250-1258.

5. Raghu AV, Geetha SP, Martin G, Balachandran I, Mohanan KV. Micropropagation of Tribulus terrestris Linn. Indian Journal of Natural Products and Resources, 2010;1(2): 232-235.

6. Armas I, Pogrebnyak N, Raskin I. A rapid and efficient in vitro regeneration system for lettuce (Lactuca sativa L.). Plant Methods, 2017;13(1):1-9.

7. Pinhal HF, Araruna E da C, Carneiro PAP, Asmar SA, Melo B de, Luz JMQ. Concentration of MS medium and cutting of seeds on in vitro establishment of baruzeiro (Dipteryx alata Vog.). Bioscience Journal, 2017;33(2):306-313.

8. Valdez M, Gatica-AAM. Effect of BAP and IAA on shoot regeneration in cotyledonary explants of Costa Rican melon genotypes. Agronomia Costarricense, 2009;33(1): 125-131.

9. Aloni R, Schwalm K, Langhans M, Ullrich CI. Gradual shifts in sites of free-auxin production during leaf-primordium development and their role in vascular differentiation and leaf morphogenesis in Arabidopsis. Planta, 2003:(5):841-853.

10. Gravel V, Antoun H, Tweddell RJ. Effect of indole-acetic acid (IAA) on the development of symptoms caused by Pythium ultimum on tomato plants. European Journal of Plant Pathology, 2007;119(4):457-462.

11. Peixe A, Raposo A, Lourenço R, Cardoso $\mathrm{H}$, Macedo E. Coconut water and BAP successfully replaced zeatin in olive (Olea europaea L.) micropropagation. Scientia Horticulturae, 2007;113(1): 1-7.

12. Antony CS, Lenin MS, Bhargav PK, Karthigan M, Ignacimuthu S. Highly efficient shoot regeneration of Bacopa monnieri (L.) using a two-stage culture procedure and assessment of genetic integrity of micropropagated plants by RAPD. Acta Physiologiae Plantarum, 2010;32(3): 443-452.

13. Mazri MA. Role of cytokinins and physical state of the culture medium to improve in vitro shoot multiplication, rooting and acclimatization of date palm (Phoenix dactylifera L.) cv. Boufeggous. Journal of Plant Biochemistry and Biotechnology, 2015;24(3): 268-275.

14. Mathieu RA, Cournède PH, de Reffye P. A dynamical model of plant growth with full retroaction between organogenesis and photosynthesis. Arima, 2006;4: 101-107.

15. Juvany M, Müller M, Munné-Bosch S. Plant age-related changes in cytokinins, leaf growth and pigment accumulation in juvenile mastic trees. Environmental and Experimental Botany, 2013;87:10-18. https://doi.org/10.1016/j.envexpbot.2012.0 9.007

16. Nakhooda M, Watt MP, \& Mycock D. Auxin stability and accumulation during in vitro shoot morphogenesis influences subsequent root induction and development in Eucalyptus grandis. Plant Growth Regulation, 2011;65(2): 263-271. https://doi.org/10.1007/s10725-011-95977

17. Vanneste S, Friml J. Auxin: a trigger for change in plant development. Cell, 2009;136(6): 1005-1016.

18. Kim HJ, Ryu H, Hong SH, Woo HR, Lim, PO, Lee IC., Hwang I. Cytokinin-mediated control of leaf longevity by AHK3 through phosphorylation of ARR2 in Arabidopsis. Proceedings of the National Academy of Sciences, 2006;103(3): 814-819.

19. Kuderová A, Urbánková I, Válková M, Malbeck J, Brzobohatý B, Némethová D, \& Hejátko J. Effects of conditional IPTdependent cytokinin overproduction on root architecture of arabidopsis seedlings. Plant and Cell Physiology, 2008;49(4): 570-582.

20. Kurakawa T, Ueda N, Maekawa M, Kobayashi K, Kojima M, Nagato Y, Kyozuka, J. Direct control of shoot meristem activity by a cytokinin-activating enzyme. Nature, 2007;445(7128): 652- 
655. https://doi.org/10.1038/nature05504

21. Riefler M, Novak O, Strnad M, Schmülling T. Hospital uses EMR to improve handoff process and create electronic "Hall Pass". The Plant Cell, 2006;18: 40-54.

22. Tran LP, Urao T, Qin F, Maruyama K, Kakimoto T, Shinozaki K, Yamaguchishinozaki K.. Functional analysis of AHK1/ATHK1 and cytokinin receptor histidine kinases in response to abscisic acid, drought, and salt stress in Arabidopsis. PNAS, 2007;104(51): 3-8. https://doi.org/10.1073/pnas.0706547105

23. Hamad AM, Taha RM. Effect of benzylaminopurine (BAP) on in vitro proliferation and growth of pineapple (Ananas comosus L. Merr.) cv. smooth cayenne. Journal of Applied Sciences, 2008;8(22): 4180-4185.

24. Zhang JY, Guo ZR, Zhang R, Li YR, Cao L, Liang YW, Huang LBin. Auxin type, auxin concentration, and air and substrate temperature difference play key: Roles in the rooting of juvenile hardwood pecan cuttings. HortTechnology, 2015; 25(2): 209-213.

25. Leyser O. Dynamic integration of auxin transport and signalling. Current Biology, 2006; 16(11): 424-433.

26. Reinhardt D, Mandel T, \& Kuhlemeier C. Auxin regulates the initiation and radial position of plant lateral organs. The Plant Cell, 2007; 12(4): 507-518.

27. Sassi M, Vernoux T. Auxin and selforganization at the shoot apical meristem. Journal of Experimental Botany, 2013;64(9): 2579-2592.
28. Karcz W, Burdach Z. Effect of temperature on growth, proton extrusion and membrane potential in maize (Zea mays L.) coleoptile segments. Plant Growth Regulation, 2007;52(2): 141-150. https://doi.org/10.1007/s10725-007-91840

29. Arimarsetiowati R, Ardiyani F. Pengaruh penambahan auxin terhadap pertunasan dan perakaran kopi arabika perbanyakan Somatik Embriogenesis. Pelita Perkebunan, 2012:28(2):82-90.

30. Akhiriana E, Samanhudi, Yunus A. Coconut water and Iaa effect on the in vitro growth of Tribulus terrestris L. Acta Universitatis Agriculturae et Silviculturae Mendelianae Brunensis, 2019;67(1): 9-18. https://doi.org/10.11118/actaun201967010 009

31. Kristina NNSFS. Pengaruh air kelapa muda terhadap multiplikasi tunas in vitro, produksi rimpang, dan kandungan xanthorrhizol temulawak di lapangan. Jurnal Litrri, 2012;18, 126-134.

32. Rahmawati F, Wicaksono KP, Aini N. Pengaruh fermentasi urin kelinci dan paitan terhadap pertumbuhan dan hasil tanaman paprika (Capsicum annuum var Grossum) dengan sistem hidroponik subtrate. Jurnal Produksi Tanaman, 2018;6(2), 194-202.

33. Prabowo H, Samanhudi, Yuniastuti E, Yunus A. Effects of media combination with concentration of ab-mix nutrient on growth of banana shoots on in vitro. Bulgarian Journal of Agricultural Science, 2018;24(3): 404-410. 